\begin{tabular}{l|l}
\hline Votaice & $\begin{array}{l}\text { e-ISSN: 2655-9404 p-ISSN: 2721-8376 } \\
\text { Dol: } 10.20473 / \text { ntr.v4i2.26123 }\end{array}$ \\
\hline
\end{tabular}

Article history: Submitted 27 March 2021; Accepted 23 May 2021; Available online 1 June 2021.

\title{
Perlindungan Hukum Pembeli Unit Rumah Susun Berdasarkan Permen Pekerjaan Umum dan Perumahan Rakyat Nomor 11/PRT/M/2019
}

\author{
Jeremia Junior Santoso \\ jeremia.junior.santoso-2018@fh.unair.ac.id \\ Universitas Airlangga
}

\begin{abstract}
Preliminary Sale and Purchase Agreement ( PPJB ) was the agreement between the builder and everyone to do trading house or a unit of apartment development before the development of the house or in process of development to the single and houses the stated in a notarial deed. Preliminary Sale and Purchase Agreement after PUPR Regulation No. 11/PRT/M/2019 are required to be made in the form of an Authentic Deed or a Notary Deed so that by making it in the form of a deed it is hoped that the rights of the parties will be more secure and minimize the losses of the parties. Because the Authentic Deed has perfect evidentiary power. Perfect in terms of proof is that the deed must be considered true and trusted by the judge. PUPR Regulation No. 11/PRT / M/2019 is here to provide the function of legal certainty for the buyer that the unit which has been partially paid according to the agreement is kept from being sold to other parties. As well as buyers who have intended to buy a house or apartment unit, while waiting for the conditions to be fulfilled or waiting for the building to be finished and have received permission to do marketing by the developer, then a Preliminary Sale and Purchase Agreement can be made first. The Preliminary Sale and Purchase Agreement has the function of preparing and strengthening the main / main agreement to be carried out, because the preliminary sale and purchase agreement is the beginning for the birth of the principal agreement. Keywords: Preliminary Sale and Purchase Agreement; Legal Protection; Consumers; Flats.
\end{abstract}

$\frac{\text { Abstrak }}{\text { Perjanjian Pendahuluan Jual Beli (PPJB) adalah kesepakatan antara pelaku pembangunan }}$ dan setiap orang untuk melakukan jual beli rumah atau satuan rumah susun yang dapat dilakukan pelaku pembangunan sebelum pembangunan untuk rumah atau dalam proses pembangunan untuk rumah tunggal dan rumah deret yang dinyatakan dalam akta notaris. Perjanjian Pendahuluan Jual Beli setelah Permen PUPR No. 11/PRT/M/2019 diharuskan untuk dibuat dalam bentuk Akta Otentik atau Akta Notaris sehingga dengan dibuatnya dalam bentuk akta diharapkan hak-hak para pihak lebih terjamin dan meminimalisir kerugian para pihak. Sebab Akta Otentik memiliki kekuatan pembuktian yang sempurna. Sempurna dalam hal pembuktian adalah akta tersebut harus dianggap benar adanya dan dipercayai oleh hakim. Permen PUPR No. 11/PRT/M/2019 hadir untuk memberikan fungsi kepastian hukum bagi pihak pembeli bahwa unit yang telah di bayarkan sebagian sesuai dengan perjanjiannya tersebut, di simpan untuk tidak dijual kepada pihak lain. Serta Pembeli yang telah berniat untuk membeli rumah atau satuan rumah susun, sembari menunggu syarat-syaratnya terpenuhi atau menunggu bangunan tersebut jadi dan telah mendapatkan izin untuk dilakukan pemasaran oleh developer maka dapat terlebih dahulu dilakukan Perjanjian Pendahuluan Jual Beli. Perjanjian Pendahuluan Jual Beli memiliki fungsi mempersiapkan serta memperkuat perjanjian pokok/utama yang akan dilakukan, sebab perjanjian pendahuluan jual beli merupakan awal untuk lahirnya perjanjian pokok. Kata Kunci: Perjanjian Pendahuluan Jual Beli; Perlindungan Hukum; Konsumen; Rumah Susun. 


\section{Pendahuluan}

Pertumbuhan penduduk pada masa sekarang di kota-kota besar sungguh pesat. Perkotaan sendiri memiliki daya tarik yang cukup tinggi akan hiburan, lapangan pekerjaan, dan fasilitas-fasilitas yang mempermudah kehidupan manusia. Perpindahan tersebut yang membuat timbulnya satu masalah sosial yaitu kurangnya tanah pemukiman bagi pendatang yang berasal dari desa. Pasal 28H ayat (1) Undang-Undang Dasar Negara Republik Indonesia Tahun 1945 (Untuk selanjutnya disebut UUD 1945) mengatur bahwa Lingkungan hidup yang baik, sehat, sejahtera lahir batin, bertempat tinggal dan memperoleh pelayanan kesehatan merupakan hak setiap orang. Amanat dari Pasal 28H ayat (1) UUD 1945 negara menjamin pemenuhan kebutuhan warga Negara atas tempat tinggal yang layak dan terjangkau dalam upaya membangun manusia Indonesia seutuhnya, berjati diri, mandiri dan produktif.

Sebagai sarana mengatasi keterbatasan tanah di kota-kota besar, sudah saatnya pemenuhan tempat tinggal atau rumah sebagai hunian di perkotaan dilakukan dengan pembangunan rumah secara vertikal dengan rumah susun. ${ }^{1}$ Pembangunan rumah susun ini merupakan pemecahan masalah atas kebutuhan perumahan dan pemukiman di daerah kota-kota besar yang memiliki jumlah penduduk yang secara terus menerus mengalami kenaikan jumlah penduduk, karena pembangunan rumah susun dapat mengurangi penggunaan tanah, membuat ruang-ruang terbuka kota yang lebih lega dan dapat digunakan sebagai suatu cara untuk peremajaan kota bagi daerah kumuh. ${ }^{2}$

Jika dikaji lebih jauh, pembangunan rumah susun merupakan salah satu sistem pembangunan pemukiman fungsional yang memiliki kelebihan, antara lain dapat mendukung konsep: ${ }^{3}$ 1991).[27]

${ }^{1}$ Siswono Judohusodo, Rumah Untuk Seluruh Rakyat (INKOPPOL Unit Percetakan Bharakerta

2 Arie S. Hutagalung, Condominium Dan Permasalahannya (Badan Penerbit Fakultas Hukum Universitas Indonesia 1998).[2].

${ }^{3}$ Wisnu Agung Edward Endrianto Pandelaki, Edi Purwanto, Deasy Olivia, 'Faktor-Faktor Pembentuk Kinerja Spasial Rumah Susun Kaitannya Dengan Kepuasan Penghuni' (2015) Vol. 15, No. 2 Jurusan Arsitektur Fakultas Teknik Universitas Diponegoro Semarang' (2015) 15 Jurnal Jurusan Arsitektur Fakultas Teknik Universitas Diponegoro Semarang.[86-87]. 
1. Konsep tata ruang yang dikaitkan dengan pembangunan wilayah perkotaan;

2. Peremajaan kota yang dikaitkan dengan usaha peningkatan efisiensi wilayah kota;

3. Efisiensi pengunaan lahan perkotaan.

Rumah susun menurut ketentuan Pasal 1 angka 1 Undang-Undang Nomor 20 Tahun 2011 (Untuk selanjutnya disebut UURS) tentang Rumah Susun adalah suatu bangunan gedung bertingkat yang dibangun dalam suatu lingkungan yang terbagi dalam bagian-bagian yang distrukturkan secara fungsional, baik dalam arah horizontal maupun vertikal dan merupakan satuan-satuan yang masing-masing dapat dimiliki dan digunakan secara terpisah, terutama untuk tempat hunian yang dilengkapi dengan bagian bersama, benda bersama dan tanah bersama. ${ }^{4}$

Down Payment memiliki kemungkinan resiko yang tinggi bagi pembeli rumah susun apabila Developer wanprestasi atau ingkar janji. Untuk menanggulangi resiko tersebut maka dikeluarkannya Peraturan Menteri Pekerjaan Umum Dan Perumahan Rakyat Nomor 11/PRT/M/2019 tentang Sistem Perjanjian Pendahuluan Jual Beli Rumah (Untuk selanjutnya disebut Permen PUPR No. 11/PRT/M/2019). Dikeluarkannya Peraturan Menteri tersebut bertujuan untuk menjaga kepentingan Developer dan pembeli rumah susun yang memerlukan pengaturan lebih lanjut tentang Perjanjian Pendahuluan Jual Beli.

Perjanjian Pendahuluan Jual Beli setelah Permen PUPR No. 11/PRT/M/2019 diharuskan untuk dibuat dalam bentuk Akta Otentik atau Akta Notaris sehingga dengan dibuatnya dalam bentuk akta diharapkan hak-hak para pihak lebih terjamin dan meminimalisir kerugian para pihak. Sebab Akta Otentik memiliki kekuatan pembuktian yang sempurna. Sempurna dalam hal pembuktian adalah akta tersebut harus dianggap benar adanya dan dipercayai oleh hakim.

Mengingat pesatnya pertumbuhan satuan rumah susun, sengketa yang terjadi pun tak terhindarkan. Developer Prasada Japa Pamudja, selaku Developer Menara Jakarta yang memasarkan unit apartment dan kantor secara aktif sejak tahun 2010, dimana selama proses pemasaran. Ia memberi janji-janji secara lisan

\footnotetext{
${ }^{4}$ Undang-Undang Nomor 20 Tahun 2011 tentang Rumah Susun (Lembaran Negara Republik Indonesia Tahun 2011 Nomor 108).
} 
bahwa Menara Jakarta yang menjadi objek jual beli tersebut sudah pada tahap penyelesaian pembangunan, memiliki kelengkapan perijinan dan segala fasilitas yang disediakan dalam Menara Jakarta serta unit lain yang dipasarkan segera selesai pada akhir tahun 2015 atau selambat-lambatnya pada awal tahun 2016, maka dari itu Penggugat tertarik untuk membeli unit di menara Jakarta yang dilakukan dengan PPJB. Pada bulan Maret 2016 pihak penggugat mengunjungi lokasi Menara Jakarta dan tidak melihat ada kegiatan ataupun aktivitas pembangunan Menara Jakarta sebagaimana diperjanjikan diawal akan selesai paling lambat awal tahun 2016. Alasan pihak tergugat tidak dapat menyelesaikan bangunan dikarenakan masih mengurus izin-izin untuk membangun Menara Jakarta dan masih belum memiliki Izin Mendirikan Bangunan untuk Menara Jakarta. ${ }^{5}$

Dari uraian di atas terlihat bahwa dalam Perjanjian Pendahuluan Jual Beli satuan rumah susun di Indonesia, pihak konsumen masih sangat dirugikan. Namun, dalam konsep hukum perjanjian, hal yang perlu diperhatikan adalah keseimbangan kepentingan antara Developer dengan kepentingan calon konsumen. Dalam praktik pelaksanaan Perjanjian Pendahuluan Jual Beli sebelum rumah susun selesai dibangun, harga jual yang telah disepakati tidak dibarengi dengan pelayanan yang baik kepada calon konsumen, sebagai contoh kualitas bahan baku, Developer terlambat menyelesaikan atau menyerahkan bangunan, fasilitas tidak sesuai dengan yang diperjanjikan dalam perjanjian, dan lain-lain. Hal ini lantas membuat konsumen merasa kecewa dan menuntut akan haknya lewat media massa, media sosial, maupun lembaga perlindungan konsumen. Perlindungan terhadap konsumen tidak hanya diberikan kepada konsumen penikmat suatu barang yang secara langsung dikonsumsi, misalnya makanan dan obat-obatan. Tetapi juga berlaku bagi konsumen yang menggunakan jasa, dalam hal ini developer menjual jasanya untuk menyediakan rumah tinggal bagi calon pemberi suatu rumah atau rumah susun. Jasa yang diberikan oleh developer tersebut dapat

${ }^{5}$ Mika Anabelle dan Hanafi Tanawijaya, 'Sistem Pre Project Selling Dalam Penjualan Satuan Unit Apartemen Menurut Undang -Undang Nomor 20 Tahun 2011 Tentang Rumah Susun (Contoh Kasus Putusan Pengadilan Negri Jakarta Pusat Nomor: 616/PDT.G/2017/PN.JKT.PST JO. Putusan Pengadilan Tinggi Jakarta Nom' (2019) 2 Jurnal Hukum Adigama.[6]. 
dibuktikan dengan bangunan yang tersedia. Oleh karena itu Pihak Pembeli satuan rumah susun dapat dikatakan bahwa adalah seorang konsumen yang dalam hal ini membeli satuan rumah susun dari pihak developer.

\section{Metode Penelitian}

Penelitian ini menggunakan metode penelitian yuridis normatif. Pendekatan yang digunakan dalam penelitian ini adalah pendekatan peraturan perundangundangan (statute approach) dan pendekatan konseptual (conceptual approach).

\section{Perjanjian Pendahuluan Jual Beli Satuan Rumah Susun Pasca Dikeluarkannya Peraturan Menteri Pekerjaan Umum Dan Perumahan Rakyat Nomor 11/ PRT/M/2019 Tentang Sistem Perjanjian Pendahuluan Jual Beli Rumah}

Negara hukum adalah negara yang segala sesuatunya diatur dengan suatu peraturan, salah satu yang dimiliki oleh negara hukum adalah administarasi negara memang memiliki ruang gerak yang sangat terbatas karena hanya memiliki fungsi hanya menjaga keamanan saja. Oleh karena itu menjadi hambatan tidak adanya ruang untuk mengambil tindakan diskresi atau penciptaan norma peraturan kebijakan (beleidregel) yang memiliki peran mengatasi problem-problem konkrit dalam kehidupan masyarakat.

Menurut Pasal 1 angka 9 Undang-Undang Nomor 30 Tahun 2014 tentang Administrasi Pemerintahan mengatur diskresi adalah keputusan dan/atau tindakan yang ditetapkan dan/atau dilakukan oleh pejabat pemerintahan untuk mengatasi persoalan konkret yang dihadapi dalam penyelenggaraan pemerintahan dalam hal peraturan perundang-undangan yang memberikan pilihan, tidak mengatur, tidak lengkap atau tidak jelas, dan/atau adanya stagnasi pemerintahan. ${ }^{6}$ Diskresi pemerintah secara harafiah sebenarnya ialah kebebasan menentukan diantara pilihan-pilihan dalam pengambilan kebijakan pemerintah. Atas dasar diskresi menghasilkan peraturan kebijakan (beleidregel).

\footnotetext{
${ }^{6}$ Undang-Undang Nomor 30 Tahun 2014 tentang Administrasi Pemerintahan (Lembaran Negara Republik Indonesia Tahun 2014 Nomor 292).
} 
Beleidsregel memiliki fungsi sebagai sarana hukum bagi pemerintahan dalam rangka fleksibilitas keberlakukan peraturan perundang-undangan untuk mengatasi stagnasi pemerintahan dalam menghadapi persoalan faktual yang tibatiba terjadi. Ketika situasi tidak lagi dalam keadaan cateris paribus atau peraturan perundang-undangan tidak lagi bisa menjawab persoalan yang dihadapi maka diskresi mengambil alih dan pelaksanaannya dapat melahirkan salah satu diantara kebaikan atau kelaliman, keadilan atau ketidakadilan, masuk akal \{dapat diterima\} atau sewenang-wenang. Hal tersebut menunjukkan bahwa diskresi adalah jantung dari kekuasaan pemerintah. ${ }^{7}$ Sehingga dikeluarkannya Permen PUPR No. 11/ PRT/M/2019 yang merupakan bentuk dari peraturan kebijakan (beleidregel). Dalam Permen PUPR No. 11/PRT/M/2019 memiliki tujuan untuk melakukan pengaturan lebih lanjut dari apa yang belum atau tidak diatur dalam UURS.

Diskresi sendiri hanya dapat dilakukan oleh Pejabat Pemerintah yang berwenang sebagaimana diatur dalam Pasal 22 ayat (1) Undang-Undang Nomor 30 Tahun 2014 tentang Administrasi Pemerintahan. Dalam hal Permen PUPR No. 11/PRT/M/2019 dikeluarkan oleh Menteri Pekerjaan Umum dan Perumahan Rakyat yang memang berwenang dan berhak mengeluarkan peraturan tersebut. Latar belakang dikeluarkannya Permen PUPR No. 11/PRT/M/2019 adalah dari Pasal 43 ayat 1 UURS yang mengatur "Proses jual beli sarusun sebelum pembangunan rumah susun selesai dapat dilakukan melalui PPJB yang dibuat di hadapan notaris" 8 dan Pasal 42 ayat 3 Undang-Undang Nomor 1 Tahun 2011 tentang Perumahan dan Kawasan Pemukiman yang mengatur "Ketentuan lebih lanjut mengenai sistem perjanjian pendahuluan jual beli sebagaimana dimaksud pada ayat (1) diatur dengan Peraturan Menteri". ${ }^{9}$

Dalam mengeluarkan aturan Permen PUPR No. 11/PRT/M/2019, Kementerian Pekerjaan Umum dan Perumahan Permukiman memiliki diskresi

\footnotetext{
${ }^{7}$ Muhammad Thabrani Mutalib, Kewenangan Pengadilan Menguji Norma Peraturan Kebijakan (Beleidsregel) Di Indonesia (Universitas Islam Indonesia 2017).[103].

${ }^{8}$ Undang-Undang Nomor 20 Tahun 2011 tentang Rumah Susun, Loc.Cit.

${ }^{9}$ Undang-Undang Nomor 1 Tahun 2011 tentang Perumahan dan Kawasan Pemukiman (Lembaran Negara Republik Indonesia Tahun 2011 Nomor 7).
} 
dalam menerbitkan aturan tersebut, karena terkait dengan persoalan perumahan dan permukiman khususnya mengatur tentang pemasaran dan penjualan rumah dan satuan rumah susun selama objeknya belum jadi dengan metode PPJB, yang sebelumnya belum diatur sehingga menimbulkan ketidak pastian. Ketentuan sebagaimana yang diatur di atas dapat terlihat bahwa Permen PUPR No. 11/ PRT/M/2019 terlihat bahwa penyelenggaraan pemerintahan dapat terlaksana dengan baik karena dalam hal sebelum dilakukan pemasaran seluruh syaratsyarat sudah melewati prosedur dan administrasi dari pemerintah. Hal ini juga berkesinambungan dengan memberikan kepastian hukum, diwujudkan dalam rangka para developer ataupun konsumen melakukan PPJB memiliki kepastian hukum serta landasan yang kuat karena telah secara rinci diatur dalam Permen PUPR No. 11/PRT/M/2019 mengenai materi muatan dalam suatu PPJB. Mengisi kekosongan hukum dalam Permen PUPR No. 11/PRT/M/2019 dilakukan dengan cara memberikan pengertian PPJB sebelumnya dalam Undang-Undang Nomor 1 Tahun 2011 tentang Perumahan dan Kawasan Pemukiman menggunakan istilah Perjanjian Pendahuluan Jual Beli sedangkan dalam UURS menggunakan istilah Perjanjian Pengikatan Jual Beli sehingga menimbulkan ketidakjelasan penggunaan istilah PPJB. Sehingga Permen PUPR No. 11/PRT/M/2019 lebih jelas menggunakan istilah Perjanjian Pendahuluan Jual Beli.

Strategi penjualan rumah atau rumah susun dengan cara pemasaran yang belum selesai dibangun atau bahkan belum dibangun merupakan strategi penjualan yang sering digunakan oleh para pengembang. Biasanya rumah susun yang dipasarkan masih dalam bentuk gambar/denah rumah susun saja, perizinan yang diwajibkan belum tuntas diurus, bahkan tidak jarang terjadi pada saat masih direncanakan dan pematangan tanah juga masih belum jelas lokasi tepatnya berada dimana. Strategi pemasaran seperti ini dalam praktik dikenal dengan istilah Pre Project Selling..$^{10}$ Secara yuridis formal pola penjualan rumah susun dengan sistem Pre Project Selling tidak dilarang. Ketentuan yang mengatur secara spesifik 2012).[13].

Y Sogar Simamora, Buku Ajar Hukum Kontrak (Fakultas Hukum Universitas Airlangga 
terkait Pre Project Selling saat itu memang belum ada, oleh karena itu landasan utama sebagai penentuan hak dan kewajiban para pihak terletak pada kebebasan berkontrak, sedangkan mekanisme penentuan hak dan kewajiban para pihak dituangkan dalam bentuk Perjanjian Pengikatan Jual Beli (PPJB). ${ }^{11}$ PPJB biasanya dilakukan sembari menunggu proses pembangunan, sehingga objek yang dijual belum pasti, masih berbentuk bangunan. Perjanjian atau kontrak merupakan salah satu dasar hukum yang menimbulkan perikatan. Definisi "perikatan" menurut doktrin (para ahli) adalah hubungan dalam bidang harta kekayaan di antara dua orang (atau lebih), dimana pihak yang satu (debitor) wajib melakukan suatu prestasi, sedangkan pihak yang lain (kreditor) berhak atas prestasi itu. ${ }^{12}$

Terciptanya PPJB maka para pihak (calon pembeli dan calon penjual) saling menyatakan kehendaknya untuk nantinya melangsungkan jual beli yang sesungguhnya. Dalam ruang lingkup hukum perjanjian, PPJB ini termasuk dalam perjanjian obligatoir. Dimaksud perjanjian obligatoir disini ialah ketika suatu perjanjian telah sah, maka perjanjian tersebut sudah mengikat, namun baru sebatas menimbulkan hak dan kewajiban saja serta pada taraf tersebut belum terjadi adanya perpindahan hak milik. Diperlukan perjanjian lain yang disebut dengan perjanjian kebendaan (zakelijke overeenkomst) untuk dapat dilakukannya penyerahan (levering) agar terjadi perpindahan hak milik. Begitu pula dengan PPJB yang baru hanya memuat hak dan kewajiban para pihak saja. Untuk peralihan haknya barulah diterbitkan perjanjian lain yang disebut dengan AJB. Itulah mengapa PPJB ini termasuk dalam kategori perjanjian obligatoir.

Permen PUPR No. 11/PRT/M/2019 diterbitkan untuk mengoptimalkan pengaturan mengenai perjanjian pengikatan jual beli satuan rumah susun yang diatur di dalam Pasal 43 Undang-Undang Nomor 20 Tahun 2011 Tentang Rumah Susun, dengan cakupan lebih luas yaitu PPJB untuk rumah umum dan rumah komersil (dalam bentuk rumah tunggal, rumah deret maupun rumah susun) yang

\footnotetext{
${ }^{11}$ ibid.[13].

${ }^{12}$ Agus Yudha Hernoko, Hukum Perjanjian Asas Proporsionalitas Dalam Kontrak Komersial (Kencana Prenada Media Group 2014).[11].
} 
mana dijelaskan dalam Pasal 2 ayat (2) Permen PUPR No. 11/PRT/M/2019. Selain itu untuk melaksanakan ketentuan di dalam Pasal 42 ayat (3) Undang-Undang Rumah Susun tentang Perumahan dan Kawasan Pemukiman. Sistem Perjanjian Pendahuluan Jual Beli ("PPJB") adalah rangkaian proses kesepakatan antara setiap orang dengan pelaku pembangunan dalam kegiatan pemasaran yang dituangkan dalam perjanjian pengikatan jual beli sebelum ditandatangani akta jual beli. ${ }^{13}$

Pemasaran adalah kegiatan yang direncanakan pelaku pembangunan untuk memperkenalkan, menawarkan, menentukan harga dan menyebarluaskan informasi tentang rumah atau perumahan dan satuan rumah susun atau rumah susun yang dilakukan oleh pelaku pembangunan pada saat sebelum atau dalam proses sebelum penandatanganan PPJB (Pasal 1 angka 3) Pelaku pembangunan dapat melakukan Pemasaran Rumah tunggal atau Rumah deret pada saat dalam tahap proses pembangunan. Dengan adanya Permen PUPR Nomor 11/ PRT/M/ 2019 tentang Sistem Perjanjian Pendahuluan Jual Beli Rumah. dijadikan dasar untuk melakukan penjualan atau pemasaran sebelum objek tersebut selesai dibangun, hal tersebut dituangkan dalam Pasal 3 Permen PUPR No. 11/ PRT/M/2019, yaitu:

(1) Pelaku pembangunan dapat melakukan Pemasaran Perumahan sebelum pembangunan dilaksanakan.

(2) Pemasaran sebagaimana dimaksud pada ayat (1) dan ayat (2) harus memuat informasi Pemasaran yang benar, jelas, dan menjamin kepastian informasi mengenai perencanaan dan kondisi fisik yang ada.

Pasal 5 Permen PUPR No. 11/PRT/M/2019 informasi pemasaran yang disampaikan kepada masyarakat, paling sedikit memuat: ${ }^{14}$

1. Nomor Surat Keterangan rencana Kabupaten Kota;

2. Nomor sertipikat hak atas tanah atas nama pelaku pembangunan atau pemilik tanah yang dikerjasamakan dengan pelaku pembangunan;

\footnotetext{
${ }^{13}$ Undang-Undang Nomor 1 Tahun 2011 tentang Perumahan dan Kawasan Pemukiman, Loc. Cit.

14 Peraturan Menteri Pekerjaan Umum Dan Perumahan Rakyat Nomor 11/PRT/M/2019 tentang Sistem Perjanjian Pendahuluan Jual Beli Rumah (Berita Negara Republik Indonesia Tahun 2019 Nomor 777).
} 
3. Surat dukungan dari bank/bukan bank;

4. Nomor dan tanggal pengesahan untuk pelaku pembangunan berbadan hokum atau nomor identitas untuk pelaku pembangunan orang perseorangan serta identitas pemilik tanah yang melakukan kerja sama dengan pelaku pembangunan;

5. Nomor dan tanggal penerbitan izin mendirikan bangunan induk atau izin mendirikan bangunan;

6. Rencana tampak perumahan atau rumah susun;

7. Spesikasi bangunan dan denah rumah atau gambar bangunan yang dipotong vertical dan memperlihatkan isi atau bagian dalam bangunan dan denah sarusun;

8. Informasi yang jelas mengenai prasarana, sarana, dan utilitas umum;

9. Informasi yang jelas mengenai bagian Bersama, benda Bersama dan tanah Bersama untuk pembangunan rumah susun.

Berdasarkan Pasal 7 ayat (2) Permen PUPR No. 11/PRT/M/2019, Kewajiban

Pelaku Pembangunan setelah menerima Pembayaran, wajib menyampaikan informasi ke calon pembeli mengenai: ${ }^{15}$

1. Jadwal pelaksanaan pembangunan;

2. Jadwal penandatanganan PPJB dan akta jual beli;

3. Jadwal serah terima rumah.

Keabsahan suatu perjanjian merupakan hal yang penting dalam hukum perjanjian karena hal ini menjadi penentu dalam proses hubungan hukum para pihak selanjutnya. Sebagaimana diketahui bahwa dalam dunia bisnis, perjanjian merupakan instrumen penting yang senantiasa membingkai hubungan hukum dan mengamankan transaksi para pihak. ${ }^{16}$ Suatu perjanjian dikatakan dapat melindungi proses hubungan hukum para pihak apabila dibuat secara sah. Agar dapat dikatakan berlaku secara sah maka perjanjian tersebut harus memenuhi syarat-syarat mengenai sahnya perjanjian yang diatur dalam Pasal 1320 BW, yaitu: ${ }^{17}$

a. Sepakat mereka yang mengikatkan dirinya (Kesepakatan/ toestemming);

b. Kecakapan untuk membuat perikatan (Kecakapan/bekwaamheid);

c. Suatu hal tertentu (Objek tertentu/ een bepaald onderwerp);

d. Suatu sebab yang diperbolehkan (Kausa/oorzaak).

${ }^{15}$ ibid.

${ }^{16}$ Agus Yudha Hernoko, Keseimbangan Versus Keadilan Dalam Kontrak (Upaya Menata Struktur Hubungan Bisnis Dalam Perspektif Kontrak Yang Berkeadilan) (2010).[22].

${ }^{17}$ Burgerlijk Wetboek (Stb. No.23 tahun 1847 tanggal 30 April 1847). 
Syarat sahnya perjanjian ini bersifat kumulatif. Artinya seluruh persyaratan tersebut harus dipenuhi agar perjanjian itu menjadi sah, dengan konsekuensi tidak dipenuhi satu atau lebih syarat dimaksud akan menyebabkan perjanjian tersebut dapat diganggu gugat keberadaannya (batal/neitig atau dapat dibatalkan/ vernietigbaar). ${ }^{18}$ Dengan telah ditandatanganinya PPJB oleh semua pihak di hadapan pejabat umum, maka PPJB tersebut termasuk ke dalam akta autentik, sehingga kedudukan akta autentik tersebut bersifat sempurna, kecuali dibuktikan sebaliknya. Perlindungan hukum kepada para pihak dilihat dari 2 (dua) perspektif atau sudut pandang, yaitu perlindungan hukum oleh: ${ }^{19}$

a. Penjual Pada PPJB terdapat hak dan kewajiban dari penjual dan pembeli. Adapun contoh yang dipraktekkan misalnya dalam PPJB mewajibkan pembeli untuk melakukan pembayaran sejumlah uang dengan ada jangka waktu yang telah disepakati, serta dikaitkan juga dengan adanya persyaratan batal apabila hal tersebut tidak dilaksanakan sesuai ketentuan PPJB. Penjual juga mempunyai kewajiban untuk melakukan penyerahan objek apabila persyaratan dalam PPJB sudah dilaksanakan, sehingga nantinya pembeli akan menandatangani BAST (Berita Acara Serah Terima) objek;

b. Pembeli Salah satu bentuk perlindungan hukum bagi pembeli dalam PPJB yaitu adanya permintaan pemberian kuasa yang tidak dapat ditarik kembali, yakni apabila kesepakatan dalam PPJB tidak terpenuhi dan/atau tidak dipenuhi oleh penjual, maka dikarenakan hal itu mengakibatkan kerugian bagi pembeli sehingga ia bisa mengajukan tuntutan atau permintaan ganti rugi atas hal tersebut.

Akta PPJB adalah jenis "partij akte", akta tersebut memuat kehendak para pihak, janji para pihak serta hak dan kewajiban para pihak, didalam akta tersebut memuat berbagai macam isi yang dikehendaki para pihak di hadapan

\footnotetext{
${ }^{18}$ Lintang Yudhantaka, 'Keabsahan Kontrak Jual Beli Rumah Susun Dengan Sistem Pre Project Selling' (2017) 32 Yuridika.[91].

${ }^{19}$ Kadek Sarna I Gusti Ayu Agung Winda Utami Dewi, I Made Dedy Priyanto, 'Perjanjian Pengikatan Jual Beli (Ppjb) Dalam Transaksi Peralihan Hak Atas Tanah Dan/Atau Bangunan’ (2019) 8 Journal Ilmu Hukum.
} 
notaris. Klausul mengenai jangka waktu pemenuhan hak dan kewajiban harus di cantumkan pada akta PPJB, sebab akan muncul ketidakpastian bagi para pihak untuk mendapatkan hak dan kewajibannya. Suatu akta akan menjadi masalah apabila salah satu pihak tidak memenuhi prestasinya atau salah satu pihak merasa dirugikan. Hal ini menyebabkan kerugian bagi para pihak yang telah membuat dan menyepakati akta yang telah dibuat, tetapi dalam perjalanannya suatu akta perjanjian tidak berjalan sesuai dengan kesepakatan para pihak yang membuatnya, terdapatnya kondisi yang berakibat suatu perjanjian harus berakhir tidak sesuai dengan kesepakatan awal.

\section{Perlindungan Hukum Terhadap Konsumen Dalam Perjanjian Pendahuluan} Jual Beli Satuan Rumah Susun Pasca Dikeluarkannya Peraturan Menteri Pekerjaan Umum Dan Perumahan Rakyat Nomor 11/PRT/M/2019 Tentang Sistem Perjanjian Pendahuluan Jual Beli Rumah

Rumah maupun satuan rumah susun yang disediakan dan kemudian dijual oleh developer, tidak menutup kemungkinan terdapat cacat dalam pembangunan, baik itu berkaitan dengan design rumah maupun bahan-bahan bangunan yang tidak baik sehingga dapat mengganggu kualitas bangunan rumah maupun rumah susun. Sehingga sebagai suatu konsumen atas rumah maupun rumah susun harus diberikan perlindungan hukum. Sarana perlindungan hukum preventif menurut Philipus M. Hadjon mengutarakan dua contoh sarana perlindungan hukum yang preventif yaitu the right to be heard dan access to information. Menurut Philipus M. Hadjon, bahwa sarana perlindungan Hukum ada dua macam, yaitu: ${ }^{20}$

1. Sarana Perlindungan Hukum Preventif Pada perlindungan hukum preventif ini, subyek hukum diberikan kesempatan untuk mengajukan keberatan atau pendapatnya sebelum suatu keputusan pemerintah mendapat bentuk yang definitif. Tujuannya adalah mencegah terjadinya sengketa. Perlindungan hukum preventif sangat besar artinya bagi tindak pemerintahan yang 
didasarkan pada kebebasan bertindak karena dengan adanya perlindungan hukum yang preventif pemerintah terdorong untuk bersifat hati-hati dalam mengambil keputusan yang didasarkan pada diskresi. Di indonesia belum ada pengaturan khusus mengenai perlindungan hukum preventif;

2. Sarana Perlindungan Hukum Represif Perlindungan hukum yang represif bertujuan untuk menyelesaikan sengketa. Penanganan perlindungan hukum oleh Pengadilan Umum dan Pengadilan Administrasi di Indonesia termasuk kategori perlindungan hukum ini. Prinsip perlindungan hukum terhadap tindakan pemerintah bertumpu dan bersumber dari konsep tentang pengakuan dan perlindungan terhadap hak-hak asasi manusia karena menurut sejarah dari barat, lahirnya konsep-konsep tentang pengakuan dan perlindungan terhadap hak-hak asasi manusia diarahkan kepada pembatasanpembatasan dan peletakan kewajiban masyarakat dan pemerintah.

Jenis cacat produk itu dapat diartikan sebagai suatu produk cacat yang disebabkan oleh satu bentuk kesalahan dalam proses pembuatan produk atau dengan kata lain, apabila suatu produk tidak dibuat sesuai dengan standar kualitas, rencana dan/atau spesifikasi produk yang dibuat oleh produsen itu sendiri seperti misalnya cacat tersembunyi yang terdapat. Sehingga apabila pembangunan rumah maupun rumah susun dibangun oleh developer dengan menggunakan bahan yang tidak sesuai dengan standart dan kualitas, dan tidak mencerminkan harga yang dibayarkan, maka konsumen berhak mendapatkan perlindungan represif. Dan perlindungan preventif sebagai konsumen yang seharusnya didapat dari dilakukannya PPJB adalah perlindungan terkait dengan pembangunan rumah maupun rumah susun dengan material terbaik yang memperkokoh bangunan tersebut.

Sebagaimana dijelaskan dalam konsideran Undang-Undang Nomor 8 Tahun 1999 Tentang Perlindungan Konsumen (Selanjutnya disebut Undang-Undang Perlindungan Konsumen), bahwa perlindungan hukum konsumen sekarang ini penting mengingat pembangunan perekonomian nasional pada era globalisasi semakin mendukung tumbuhnya dunia usaha yang menghasilkan beraneka ragam produk barang dan atau jasa yang memiliki kandungan teknologi. Tujuan 
dan asas yang terdapat dalam Undang-Undang Perlindungan Konsumen maka kedudukan konsumen jelas sebagai pihak yang harus di lindungi akan peredaran produk-produk yang dihasilkan oleh pelaku usaha. Sehingga apabila konsumen meresa dirugikan maka dapat melakukan gugatan kepada pelaku usaha tersebut. Menyangkut pengaduan konsumen, Pasal 4 butir d Undang-Undang Perlindungan Konsumen, konsumen memiliki hak untuk didengar pendapatnya dan keluhannya atas barang dan atau jasa yang digunakan. Tak hanya itu, ia juga memiliki hak untuk mendapatkan advokasi, perlindungan dan upaya penyelesaian sengeketa perlindungan konsumen secara patut. ${ }^{21}$

Perlindungan terhadap konsumen tidak hanya diberikan kepada konsumen penikmat suatu barang yang secara langsung dikonsumsi, misalnya makanan dan obat-obatan. Tetapi juga berlaku bagi konsumen yang menggunakan jasa, dalam hal ini developer menjual jasanya untuk menyediakan rumah tinggal bagi calon pemberi suatu rumah atau rumah susun. Jasa yang diberikan oleh developer tersebut dapat dibuktikan dengan bangunan yang tersedia. Sehingga bangunan tersebut merupakan benda yang dapat dinikmati karena adanya jual beli antara pembeli dan developer. Permen PUPR No. 11/PRT/M/2019 mengatur tentang Perjanjian Pendahuluan Jual Beli (PPJB) yang dapat dilakukan oleh para pihak apabila syarat jual-beli belum terpenuhi.

Dalam Pasal 13 Permen PUPR No. 11/PRT/M/2019 juga menunjukan bahwa PPJB tersebut melindungi dan lebih menguntungkan pihak pembeli selaku konsumen, sebagai berikut: ${ }^{22}$

(1) Dalam hal pembatalan pembelian Rumah setelah penandatanganan PPJB karena kelalaian pelaku pembangunan maka seluruh pembayaran yang telah diterima harus dikembalikan kepada pembeli;

(2) Dalam hal pembatalan pembelian Rumah setelah penandatanganan PPJB karena kelalaian pembeli maka:

\footnotetext{
${ }^{21}$ Yusuf Shofie, Penyelesaian Sengketa Konsumen Menurut UUPK, Teori Dan Praktek Penegakan Hukum (Citra Aditya Bakti 2003).[90].

${ }_{22}$ Peraturan Menteri Pekerjaan Umum Dan Perumahan Rakyat Nomor 11/PRT/M/2019 tentang Sistem Perjanjian Pendahuluan Jual Beli Rumah, Loc.Cit.
} 
a. jika pembayaran telah dilakukan pembeli paling tinggi 10\% (sepuluh persen) dari harga transaksi, keseluruhan pembayaran menjadi hak pelaku pembangunan; atau

b. jika pembayaran telah dilakukan pembeli lebih dari $10 \%$ (sepuluh persen) dari harga transaksi, pelaku pembangunan berhak memotong $10 \%$ (sepuluh persen) dari harga transaksi.

Undang-Undang Nomor 5 Tahun 1960 Tentang Peraturan Dasar Pokok-Pokok Agraria (selanjutnya disingkat UUPA) tidak mengatur mengenai jual-beli secara khusus. Dalam Pasal 5 UUPA mengatur bahwa "Hukum Agraria yang berlaku atas bumi, air dan ruang angkasa ialah hukum adat..." dari pengertian tersebut dapat diketahui bahwa asas dan sistem yang dipakai dalam hukum tanah nasional adalah hukum tanah adat. Jual beli tanah dalam UUPA memiliki arti tindakan hukum berupa penyerahan hak milik dari penjual kepada pembeli yang diikuti dengan pembayaran sejumlah harga kepada penjual yang memiliki sifat, yaitu: ${ }^{23}$

1. Terang memiliki pengertian bahwa jual-beli dilakukan dihadapan kepala desa sebagai tanda jual-beli tanah tersebut tidak melanggar ketentuan hukum yang berlaku, dalam perkembangannya sifat terang ini jual-beli tanah yang sudah bersertipikat dilakukan dihadapan Pejabat Pembuat Akta Tanah (PPAT) yang berwenang;

2. Tunai memiliki pengertian adanya pembayaran sejumlah uang sebagai pembayaran harga oleh pembeli tanah kepada penjual tanah;

3. Riil memiliki pengertian adanya kehendak pembeli dan penjual untuk melakukan jual-beli tanah diikuti oleh pembayaran sejumlah uang oleh pembeli kepada penjual.

Dalam rangka jual beli hak atas tanah atau Hak Milik Atas Satuan Rumah Susun perlu dilakukan tahapan-tahapan sampai terjadinya peralihan hak dari penjual ke pembeli agar dikemudian hari tidak terjadi hal-hal yang merugikan pembeli, misalnya tanah dalam keadaan sengketa ataupun tanah dalam keadaan

\footnotetext{
${ }^{23}$ Boedi Harsono, Hukum Agraria Indonesia: Sejarah Pembentukan Undang-Undang Pokok Agraria, Isi Dan Pelaksanaannya (Djambatan 1997).[333].
} 
sedang dijaminkan ke Bank. Hal-hal yang perlu diperhatikan dalam jual beli tanah adalah penjual dan pembeli. Syarat Materiil dan syarat Formal harus dipenuhi oleh penjual dan pembeli demi tercapainya jual-beli yang aman dan tidak merugikan pihak manapun.

Penjualan terhadap objek rumah atau satuan rumah susun maka dapat dilakukan dengan memperhatikan ketentuan dari Pasal 4 Permen PUPR No. 11/ PRT/M/2019 yang mengatur: ${ }^{24}$

(1) Pelaku pembangunan yang melakukan Pemasaran sebagaimana dimaksud dalam Pasal 3 ayat (1) dan ayat (2) harus memiliki paling sedikit:

a. kepastian peruntukan ruang;

b. kepastian hak atas tanah;

c. kepastian status penguasaan Rumah;

d. perizinan pembangunan perumahan atau Rumah Susun; dan

e. jaminan atas pembangunan perumahan atau Rumah Susun dari lembaga penjamin.

(2) Kepastian peruntukan ruang sebagaimana dimaksud pada ayat (1) huruf a, dibuktikan dengan surat keterangan rencana kabupaten/kota yang sudah disetujui Pemerintah Daerah.

(3) Kepastian hak atas tanah sebagaimana dimaksud pada ayat (1) huruf b, dibuktikan dengan sertipikat hak atas tanah atas nama pelaku pembangunan atau sertipikat hak atas tanah atas nama pemilik tanah yang dikerjasamakan dengan pelaku pembangunan.

(4) Dalam hal hak atas tanah masih atas nama pemilik tanah yang dikerjasamakan dengan pelaku pembangunan sebagaimana dimaksud pada ayat (3), pelaku pembangunan harus menjamin dan menjelaskan kepastian status penguasaan tanah.

(5) Kepastian status penguasaan Rumah sebagaimana dimaksud pada ayat (1) huruf c, diberikan oleh pelaku pembangunan dengan menjamin dan menjelaskan mengenai bukti penguasaan yang akan diterbitkan dalam nama pemilik Rumah yang terdiri atas:

a. status sertipikat hak milik, sertipikat hak guna bangunan, dan sertipikat hak pakai untuk Rumah tunggal atau Rumah deret; dan

b. sertifikat hak milik atas Sarusun atau sertifikat kepemilikan bangunan gedung Sarusun untuk Rumah Susun yang ditunjukkan berdasarkan pertelaan yang disahkan oleh Pemerintah Daerah kabupaten/kota atau Pemerintah Daerah Provinsi khusus Provinsi Daerah Khusus Ibukota Jakarta.

(6) Perizinan pembangunan perumahan pada Rumah tunggal, Rumah deret atau RumahSusun sebagaimana dimaksud pada ayat (1) huruf d, dibuktikan dengan

${ }^{24}$ Peraturan Menteri Pekerjaan Umum Dan Perumahan Rakyat Nomor 11/PRT/M/2019 tentang Sistem Perjanjian Pendahuluan Jual Beli Rumah, Loc.Cit 
surat izin mendirikan bangunan induk atau izin mendirikan bangunan.

(7) Jaminan atas pembangunan perumahan pada Rumah tunggal, Rumah deret atau Rumah Susun dari lembaga penjamin sebagaimana dimaksud pada ayat (1) huruf e, dibuktikan pelaku pembangunan berupa surat dukungan bank atau bukan bank.

(8) Pengawasan terhadap persyaratan Pemasaran sebagaimana dimaksud pada ayat (1) dilakukan oleh perangkat daerah yang membidangi perumahan dan kawasan permukiman Pemerintah Daerah kabupaten/kota atau Pemerintah Daerah provinsi khusus untuk Provinsi Daerah Khusus Ibukota Jakarta.

Pasal 4 Permen PUPR No. 11/PRT/M/2019 secara implisit memberikan perlindungan hukum terhadap konsumen dalam hal ini adalah calon pembeli rumah maupun pembeli satuan rumah susun. Bahwa Perjanjian Pendahuluan Jual Beli (PPJB) dapat dilakukan dengan memperhatikan kewajiban dari masingmasing pihak, dan pihak developer selaku penyedia bangunan juga harus dapat menjamin kepastian hukum atas status rumah dan bangunan maupun rumah susun tersebut. Hal demikian merupakan bentuk jaminan perlindungan terhadap pihak pembeli selaku konsumen.

Setelah kementerian PUPR menerbitkan aturan berupa Peraturan Menteri Pekerjaan Umum Dan Perumahan Rakyat Nomor 11/PRT/M/2019 Tentang Sistem Perjanjian Pendahuluan Jual Beli Rumah, maka semakin jelas bahwa pemerintah mendukung adanya proses penjualan sebelum unit perumahan atau satuan rumah susun tersebut selesai tahap pembangunan, atau yang lebih dikenal dengan istilah Pre Project Selling. Pasal 3 Permen PUPR No. 11/PRT/M/2019 mengatur sebagai berikut: ${ }^{25}$

(1) Pelaku pembangunan dapat melakukan Pemasaran Rumah tunggal atau Rumah deret pada saat dalam tahap proses pembangunan.

(2) Pelaku pembangunan dapat melakukan Pemasaran Rumah Susun sebelum pembangunan dilaksanakan.

(3) Pemasaran sebagaimana dimaksud pada ayat (1) dan ayat (2) harus memuat informasi Pemasaran yang benar, jelas, dan menjamin kepastian informasi mengenai perencanaan dan kondisi fisik yang ada. 
Perjanjian dapat terlaksana dengan baik apabila para pihak telah memenuhi prestasinya masing-masing seperti yang telah diperjanjikan tanpa ada pihak yang dirugikan. Namun ada kalanya perjanjian tersebut tidak terlaksana dengan baik karena adanya wanprestasi yang dilakukan oleh salah pihak. Adapun yang dimaksud wanprestasi adalah suatu keadaan yang dikarenakan kelalaian atau kesalahannya, sehingga debitur tidak dapat memenuhi prestasi seperti yang telah yang telah ditentukan dalam perjanjian dan bukan dalam keadaan yang memaksa. Wanprestasi itu dapat berupa perbuatan: ${ }^{26}$

1. Sama sekali tidak memenuhi prestasi, tidak memenuhi prestasi sama sekali, sehubungan dengan debitur yang tidak memenuhi prestasi maka dikatakan debitur tidak memenuhi prestasi sama sekali. Dalam hal ini pemenuhan prestasi bagi para pihak dalam sewa-menyewa, tidak boleh salah satu pihak melanggar dari isi perjanjian keduanya. Apabila telah diperjanjikan maka harus disepakati, adapun terkait dengan kontrak perpanjangan otomatis tersebut juga harus dilakukan kecuali para pihak menginginkan perubahan.

2. Prestasi yang dilakukan tidak sempurna, memenuhi prestasi tetapi tidak sesuai atau keliru, debitur yang memenuhi prestasi tapi keliru, apabila prestasi yang keliru tersebut tidak dapat diperbaiki lagi maka debitur dikatakan tidak memenuhi prestasi sama sekali.

3. Terlambat memenuhi prestasi, Memenuhi prestasi tetapi tidak tepat waktunya, apabila prestasi debitur masih dapat diharapkan pemenuhannya, maka debitur dianggap memenuhi prestasi tetapi tidak tepat waktu, sehingga dapat dikatakan wanprestasi. Dalam hal ini apabila kontrak sewa menyewa tersebut telah melarang untuk melakukan pembayaran dengan waktu yang ditentukan, tetapi pembayaran tersebut dilakukan pembayaran dengan waktu yang tidak sesuai.

4. Melakukan apa yang dalam perjanjian dilarang untuk dilakukan.

Salah satu hal yang sangat penting dari tidak dipenuhinya perikatan ialah bahwa kreditur dapat minta ganti rugi atas ongkos, rugi dan bunga yang dideritanya. Membolehkan adanya kewajiban ganti rugi bagi debitur maka Undang-Undang menentukan bahwa debitur harus terlebih dahulu dinyatakan berada dalam keadaan lalai. Wanprestasi pada umumnya adalah karena kesalahan debitur, namun ada kalanya debitur yang dituduh lalai dapat membela dirinya karena ia tidak sepenuhnya bersalah, atau dengan kata lain kesalahan debitur tidak

${ }^{26}$ Ahmadi Miru, Hukum Kontrak Dan Perancangan Kontrak (Rajawali Pers 2007).[74]. 
disebabkan sepenuhnya karena kesalahannya. Penetapan suatu pihak melakukan wanprestasi adalah dalam perjanjian, yang bertujuan untuk tidak melakukan suatu perbuatan.

Pasal 9 Permen PUPR No. 11/PRT/M/2019 mengatur sebagai berikut:

(1) Dalam hal pelaku pembangunan lalai memenuhi jadwal sebagaimana dimaksud dalam Pasal 7 ayat (2) huruf a dan/atau huruf b, calon pembeli dapat membatalkan pembelian Rumah tunggal, Rumah deret atau Rumah Susun.

(2) Apabila calon pembeli membatalkan pembelian Rumah tunggal, Rumah deret atau Rumah Susun sebagaimana dimaksud pada ayat (1), seluruh pembayaran yang diterima pelaku pembangunan harus dikembalikan sepenuhnya kepada calon pembeli.

(3) Dalam hal pembatalan pembelian Rumah tunggal, Rumah deret atau Rumah Susun pada saat Pemasaran oleh calon pembeli yang bukan disebabkan oleh kelalaian pelaku pembangunan, maka pelaku pembangunan mengembalikan pembayaran yang telah diterima kepada calon pembeli dengan dapat memotong $10 \%$ (sepuluh persen) dari pembayaran yang telah diterima oleh pelaku pembangunan ditambah atas biaya pajak yang telah diperhitungkan.

(4) Pembatalan sebagaimana dimaksud pada ayat (2) dan ayat (3) disampaikan secara tertulis.

(5) Pengembalian pembayaran sebagaimana dimaksud pada ayat (2) atau dalam hal terdapat sisa uang pembayaran setelah diperhitungkan dengan pemotongan sebagai dimaksud pada ayat (3) dilaksanakan paling lambat 30 (tiga puluh) hari kalender sejak surat pembatalan ditandatangani.

(6) Dalam hal pengembalian pembayaran dalam jangka waktu sebagaimana dimaksud pada ayat (5) tidak terlaksana, pelaku pembangunan dikenakan denda sebesar 1\%o (satu per-mil) per-hari kalender keterlambatan pengembalian dihitung dari jumlah pembayaran yang harus dikembalikan.

Pembeli yang telah berniat untuk membeli rumah atau satuan rumah susun, sembari menunggu syarat-syaratnya terpenuhi atau menunggu bangunan tersebut jadi dan telah mendapatkan izin untuk dilakukan pemasaran oleh developer maka dapat terlebih dahulu dilakukan Perjanjian Pendahuluan Jual Beli (PPJB). Dan Perjanjian Pendahuluan Jual Beli (PPJB) ini memiliki akibat hukum untuk kepastian bagi pihak pembeli bahwa unit yang telah di bayarkan sebagian sesuai dengan perjanjiannya tersebut, di simpan untuk tidak dijual kepada pihak lain. Bagi pihak developer juga demikian, mendapatkan kepastian dan dana yang masuk terlebih dahulu untuk menambah pemasukan demi menyelesaikan pekerjaannya. 
Akibat hukum dari dikeluarkannya Permen PUPR No. 11/PRT/M/2019 terdapat kepastian hukum dan perlindungan hukum bagi para calon pembeli, tetapi juga dapat dilihat terdapat ketimpangan terhadap posisi developer selaku calon penjual. Terdapat perlindungan hukum bagi para pihak untuk melindungi kepentingannya dan memberikan suatu kepastian hukum dalam akta PPJB. Pembeli juga mempunyai kewajiban utama untuk membayar harga dari apa yang dibelinya itu, pada waktu dan di tempat sebagaimana ditetapkan menurut persetujuan/perjanjian yang bersangkutan dengan aturan tambahan bahwa jika para pihak tidak menentukannya, pembayaran itu harus dilakukan di tempat pada waktu penyerahan benda itu.

Perlindungan terhadap calon pembeli juga dituangakan dalam Pasal 13 Permen PUPR No. 11/PRT/M/2019:27

(1) Dalam hal pembatalan pembelian Rumah setelah penandatanganan PPJB karena kelalaian pelaku pembangunan maka seluruh pembayaran yang telah diterima harus dikembalikan kepada pembeli.

(2) Dalam hal pembatalan pembelian Rumah setelah penandatanganan PPJB karena kelalaian pembeli maka:

a. jika pembayaran telah dilakukan pembeli paling tinggi 10\% (sepuluh persen) dari harga transaksi, keseluruhan pembayaran menjadi hak pelaku pembangunan; atau

b. jika pembayaran telah dilakukan pembeli lebih dari 10\% (sepuluh persen) dari harga transaksi, pelaku pembangunan berhak memotong $10 \%$ (sepuluh persen) dari harga transaksi.

Perlindungan terhadap calon penjual, perlindungan terhadap pembeli biasanya selain dilakukan dengan persyaratan juga di ikuti dengan permintaaan pemberian kuasa yang tidak dapat ditarik kembali. Tujuannya adalah apabila pihak penjual tidak memenuhinya maka pihak pembeli dapat menuntut dan dan memintakan ganti rugi sesuai dengan kesepakatan yang diatur dalam perjanjian pengikatan jual beli. Dengan demikian, perlindungan hukum yang dapat diberikan kepada semua pihak dalam PPJB. Selain perlindungan hukum akta PPJB juga berlandaskan Pasal 1338 BW yang berasaskan kebebasan berkontrak, serta niat baik dari para pihak untuk memenuhi kesepakatan yang telah dibuat.

${ }^{27}$ Peraturan Menteri Pekerjaan Umum Dan Perumahan Rakyat Nomor 11/PRT/M/2019 tentang Sistem Perjanjian Pendahuluan Jual Beli Rumah, Loc.Cit. 
Penulisan ini memberikan contoh sebuah kasus Developer Prasada Japa Pamudja, selaku Developer Menara Jakarta yang memasarkan unit apartment dan kantor secara aktif sejak tahun 2010, dimana selama proses pemasaran. Ia memberi janji-janji secara lisan bahwa Menara Jakarta yang menjadi objek jual beli tersebut sudah pada tahap penyelesaian pembangunan, memiliki kelengkapan perijinan dan segala fasilitas yang disediakan dalam Menara Jakarta serta unit lain yang dipasarkan segera selesai pada akhir tahun 2015 atau selambat-lambatnya pada awal tahun 2016, maka dari itu Penggugat tertarik untuk membeli unit di menara Jakarta yang dilakukan dengan PPJB.

Pada bulan Maret 2016 pihak penggugat mengunjungi lokasi Menara Jakarta dan tidak melihat ada kegiatan ataupun aktivitas pembangunan Menara Jakarta sebagaimana diperjanjikan diawal akan selesai paling lambat awal tahun 2016. Alasan pihak tergugat tidak dapat menyelesaikan bangunan dikarenakan masih mengurus izin-izin untuk membangun Menara Jakarta dan masih belum memiliki Izin Mendirikan Bangunan untuk Menara Jakarta. Atas dasar Pasal 13 Permen PUPR No. 11/PRT/M/2019 tergugat selaku pembeli dalam PPJB ini mendapatkan perlindungan akibat kelalaian yang dilakukan oleh penggugat yaitu Menara Jakarta. Pasca berlakunya Permen PUPR No. 11/ PRT/M/2019 kedudukan pembeli selaku konsumen dalam PPJB ini menjadi terlindungi.

\section{Kesimpulan}

Permen PUPR No. 11/PRT/M/2019 hadir sebagai jawaban atas Pasal 43 ayat (1) UURS dan Pasal 42 ayat (3) Undang-Undang Nomor 1 Tahun 2011. Permen PUPR No. 11/PRT/M/2019 mengatur tentang pemasaran dan penjualan rumah dan satuan rumah susun selama objeknya belum jadi dengan metode Perjanjian Pendahuluan Jual Beli, yang sebelumnya belum diatur sehingga menimbulkan ketidak pastian. Hal ini memberikan kepastian hukum, para developer ataupun konsumen melakukan Perjanjian Pendahuluan Jual Beli memiliki kepastian hukum serta landasan yang kuat karena telah secara rinci diatur mengenai 
materi muatan Perjanjian Pendahuluan Jual Beli. Mengisi kekosongan hukum dilakukan dengan cara memberikan pengertian Perjanjian Pendahuluan Jual Beli sebelumnya dalam Undang-Undang Nomor 1 Tahun 2011 menggunakan istilah Perjanjian Pendahuluan Jual Beli sedangkan dalam UURS menggunakan istilah Perjanjian Pengikatan Jual Beli sehingga menimbulkan ketidakjelasan penggunaan istilah Perjanjian Pendahuluan Jual Beli. Sehingga Permen PUPR No. 11/PRT/M/2019 lebih jelas menggunakan istilah Perjanjian Pendahuluan Jual Beli.

Permen PUPR No. 11/PRT/M/2019 memberikan perlindungan hukum bagi konsumen dengan cara memberikan manfaaat kepastian hukum. Melalui Pasal 4 Permen PUPR No. 11/PRT/M/2019, secara implisit memberikan perlindungan hukum terhadap konsumen dalam hal ini adalah calon pembeli rumah maupun pembeli satuan rumah susun. Bahwa Perjanjian Pendahuluan Jual Beli dapat dilakukan dengan memperhatikan kewajiban dari masingmasing pihak, dan pihak developer selaku penyedia bangunan juga harus dapat menjamin kepastian hukum atas status rumah dan bangunan maupun rumah susun tersebut. Selain itu melalui Pasal 9 Permen PUPR No. 11/PRT/M/2019 mencerimkan perlindungan hukum berbentuk kepastian hukum Pembeli yang telah berniat untuk membeli rumah atau satuan rumah susun, sembari menunggu syarat-syaratnya terpenuhi atau menunggu bangunan tersebut jadi dan telah mendapatkan izin untuk dilakukan pemasaran oleh developer maka dapat terlebih dahulu dilakukan Perjanjian Pendahuluan Jual Beli. Serta Perjanjian Pendahuluan Jual Beli ini memiliki akibat hukum untuk kepastian bagi pihak pembeli bahwa unit yang telah di bayarkan sebagian sesuai dengan perjanjiannya tersebut, di simpan untuk tidak dijual kepada pihak lain. Bagi pihak developer juga demikian, mendapatkan kepastian dan dana yang masuk terlebih dahulu untuk menambah pemasukan demi menyelesaikan pekerjaannya. Perjanjian Pendahuluan Jual Beli yang dilakukan oleh para pihak tersebut harus melindungi kepentingan masingmasing pihak. 


\section{Daftar Bacaan}

\section{Buku}

Agus Yudha Hernoko, Keseimbangan Versus Keadilan Dalam Kontrak (Upaya Menata Struktur Hubungan Bisnis Dalam Perspektif Kontrak Yang Berkeadilan) (2010).

Agus Yudha Hernoko, Hukum Perjanjian Asas Proporsionalitas Dalam Kontrak Komersial (Kencana Prenada Media Group 2014).

Ahmadi Miru, Hukum Kontrak Dan Perancangan Kontrak (Rajawali Pers 2007).

Arie S. Hutagalung, Condominium Dan Permasalahannya (Badan Penerbit Fakultas Hukum Universitas Indonesia 1998).

Boedi Harsono, Hukum Agraria Indonesia: Sejarah Pembentukan Undang-Undang Pokok Agraria, Isi Dan Pelaksanaannya (Djambatan 1997).

Muhammad Thabrani Mutalib, Kewenangan Pengadilan Menguji Norma Peraturan Kebijakan (Beleidsregel) Di Indonesia (Universitas Islam Indonesia 2017).

Simamora YS, Buku Ajar Hukum Kontrak (Fakultas Hukum Universitas Airlangga 2012).

Siswono Judohusodo, Rumah Untuk Seluruh Rakyat (INKOPPOL Unit Percetakan Bharakerta 1991).

Yusuf Shofie, Penyelesaian Sengketa Konsumen Menurut UUPK, Teori Dan Praktek Penegakan Hukum (Citra Aditya Bakti 2003).

Jurnal

Edward Endrianto Pandelaki, Edi Purwanto, Deasy Olivia WA, 'Faktor-Faktor Pembentuk Kinerja Spasial Rumah Susun Kaitannya Dengan Kepuasan Penghuni' (2015) Vol.15, No. 2 Jurusan Arsitektur Fakultas Teknik Universitas Diponegoro Semarang' (2015) 15 Jurnal Jurusan Arsitektur Fakultas Teknik Universitas Diponegoro Semarang.

Hadjon PM, Perlindungan Hukum Bagi Rakyat Di Indonesia (Bina Ilmu 1987).

I Gusti Ayu Agung Winda Utami Dewi, I Made Dedy Priyanto KS, 'Perjanjian Pengikatan Jual Beli (Ppjb) Dalam Transaksi Peralihan Hak Atas Tanah Dan/Atau Bangunan' (2019) 8 Journal Ilmu Hukum.

Lintang Yudhantaka, 'Keabsahan Kontrak Jual Beli Rumah Susun Dengan Sistem Pre Project Selling' (2017) 32 Yuridika. 
Mika Anabelle dan Hanafi Tanawijaya, 'Sistem Pre Project Selling Dalam Penjualan Satuan Unit Apartemen Menurut Undang -Undang Nomor 20 Tahun 2011 Tentang Rumah Susun (Contoh Kasus Putusan Pengadilan Negri Jakarta Pusat Nomor: 616/PDT.G/2017/PN.JKT.PST JO. Putusan Pengadilan Tinggi Jakarta Nom' (2019) 2 Jurnal Hukum Adigama.

\section{Perundang-undangan}

Burgerlijk Wetboek (Stb. No.23 tahun 1847 tanggal 30 April 1847).

Undang-Undang Republik Indonesia Nomor 5 tahun 1960 tentang Peraturan Dasar Pokok-Pokok Agraria (Lembaran Negara Republik Indonesia Tahun 1960 Nomor 104, Tambahan Lembaran Negara Republik Indonesia Nomor 2043).

Undang-Undang Republik Indonesia Nomor 8 tahun 1999 tentang Perlindungan Konsumen (Lembaran Negara Republik Indonesia Tahun 1999 Nomor 42, Tambahan Lembaran Negara Republik Indonesia Nomor 3821).

Undang-Undang Republik Indonesia Nomor 1 Tahun 2011 tentang Perumahan dan Kawasan Pemukiman. (Lembaran Negara Republik Indonesia Tahun 2011 Nomor 7).

Undang-Undang Republik Indonesia Nomor 20 Tahun 2011 tentang Rumah Susun. (Lembaran Negara Republik Indonesia Tahun 2011 Nomor 108, Tambahan Lembaran Negara Republik Indonesia Nomor 5252).

Undang-Undang Nomor 30 Tahun 2014 tentang Administrasi Pemerintahan (Lembaran Negara Republik Indonesia Tahun 2014 Nomor 292, Tambahan Lembaran Negara Republik Indonesia Nomor 5601).

Peraturan Menteri Pekerjaan Umum Dan Perumahan Rakyat Nomor 11/ PRT/M/2019 tentang Sistem Perjanjian Pendahuluan Jual Beli Rumah (Berita Negara Republik Indonesia Tahun 2019 Nomor 777).

How to cite: Jeremia Junior Santoso, 'Perlindungan Hukum Pembeli Unit Rumah Susun Berdasarkan Permen Pekerjaan Umum dan Perumahan Rakyat Nomor 11/PRT/M/2019’ (2021) Vol. 4 No. 2 Notaire. 